\title{
Reproductive biology of the Salema, fish Sarpa salpa (Osteichthyes: Sparidae) along the eastern coast of Libya.
}

\author{
Salah G. El-Etreby ${ }^{1}$; Ashraf I. Ahmed ${ }^{1}$; Magdy A. Alwany ${ }^{1}$ and Randa A. Ali. ${ }^{2}$ \\ 1- Marine Science Dept., Faculty of Science, Suez Canal University, Egypt \\ 2- Omar Elmoktar University, Libya
}

\section{ABSTRACT}

In the current work, the overall ratio between males and females of Sarpa salpa was 1:0.32. The first sexual maturity of males was recorded at length group (21.1$24 \mathrm{~cm})$ by $66.6 \%$ and the female was recorded at length group (24.1-27) by $50 \%$. Ovaries of $S$. salpa were examined. The smallest mature female had a total body length of $29 \mathrm{~cm}$ and $387.73 \mathrm{gm}$ weight with absolute fecundity of 2,978,440 eggs. The largest female had total body length of $39 \mathrm{~cm}$ and body weight of $918.86 \mathrm{gm}$ with absolute fecundity 1,685,729 eggs. Based on the results of maturity stages, gonadosomatic indices (G.S.I) and ova diameters, the study showed clearly that spawning season of $S$. salpa in the Libyan coast of the Mediterranean waters extends from October to December.

Keyword: Sarpa salpa, Salema fish, reproduction, Mediterranean Sea

\section{INTRODUCTION}

Reproduction is acyclic phenomenon which occurs periodically in fish, usually once or several times a year but some time once every two or three years. Rhythm is defined as succession of reproductive cycles, rhythmicity can hardly be an innate characteristic, since the cyclic reproductive activity is usually considered from adaptation to changing environment mediated through the endocrine system (Billard \& Breton, 1978).

Coordination of the environmental and the reproductive cycles is achieved by proximate timing factors, these and few generalization are possible, day length and temperature are commonly important variables, but many others are involved and it is the interplay of many Libya factors including those stimulating gonad regression, which achieves the regulation of the cycle and the coordination of cycles population individuals (Sott, 1979). Both \& Buxton (1997) studied the biological properties of Pterogymnus laniaries on the shores of South Africa. There are some studied conducted on some fishes of family sparidae in south Sinai coasts; Rhaldosargua haffara, Diplodus noct and Rhabdosargus sarba (Ahmed, 1999). Also study was conducted on the fish Pagellus eirythrinus, the overall ratio of males to females was 1: 3.16, the duration of reproductive season was from April to October and the peak in spawning activity occurred in August - September (Belgin \& Raziye, 2003). In a study conducted on $S$. salpa, along the Italian Mediterranean coast, two distinct spawning periods were observed. One in spring from March to May and the other in autumn from end of September to November (Alessandro et al., 2006). The abundance of $S$. rivulatus (more than $S$. luridus and native fish species $S$. salpa and Sparisoma cretense) was in the eastern region of the Libyan coast. In the Gulf of Sirt region the exotic herbivore $S$. luridus was more abundant than Sianus rivulatus and the native fishspecies S. salpa and Sparisoma cretense (Shakman, 2008). This work aims to study the reproductive biology in vicinity of sex ratio, monthly variations in 
maturity stages, egg diameter, Gonado index. Besides studying the length at first maturation and fecundity. This information helps keep these S.salpa in the spawning season.

\section{MATERIALS AND METHODS}

\section{1- Sex ratio:}

Sex of $S$. salpa was determined after dissection and the gonads were removed and wet weighed to the nearest $\mathrm{mg}$. The sex ratio of fish population refers to the frequency or the percentages of males to females in the population or catch, which was determined visually.

\section{2- First sexual maturity:}

The length at first sexual maturity is defined as the length at which $50 \%$ of fish reach sexual maturity (Pitt, 1970). Such information is essential for the conservation of an exploited fish stock through the estimation of minimum legal size, which is needed to secure spawning part of fish population.

\section{3- Maturity stages:}

Fish maturity was classified to five stages according to Hjort (1910):

I- Immature; the ovaries and testes were transparent and thread - like. In this stage the two sexes were very difficult to differentiate. However, male gonads are ribbon shaped, while female gonads are more cylindrical.

II- Maturing; testes and ovaries are reddish in color and occupy one - third of the body cavity. The male gonads are clearly flattened, while female gonads are cylindrical.

III- Mature; the male and female gonads are enlarged in size and occupy about two - third of the body cavity. The testes are reddish or partially white; blood vessels are seen within the developing tests. The ovary is yellow in color and also invaded with blood vessels. Some small ova start to be visible to the naked eye.

IV- Spawning (running); in this stage, the testes and ovaries are in their maximum development. In ovaries, more advanced eggs can be seen, which can be extruded upon applying a very slight pressure on the belly.

$\mathrm{V}$ - Spent; at the end of spawning season the ovaries and testes decreased sharply in weight and became flaccid, inside the ovary few ova left but most of the tissues are empty follicles after extruding most of the ova to the water. Usually this stage is difficult to identify with naked eye but identified clearly with histology; generally it is added for this reason to immature stage.

In the present study, it was difficult to distinguish precisely each stage separately, therefore it was grouped together to be easy distinguish as follows:

1- Stages I \& II are grouped together and classified as immature.

2- Stage III which was easily recognized and was considered as mature.

3- Stage IV was classified as spawning.

Gonads of the specimens were preserved in $4 \%$ formalin for detailed study.

\section{4- Gonado - Somatic Index (G.S.I)}

A widely used method to index reproductive condition has been expressed as gonad weight as a percentage of body weight (De Vlamming et al., 1982). The monthly Ganado - Somatic Index (G.S.I) was calculated from the following formula

G.S.I = wet weight of gonad (gm.) / wet weight of fish $(\mathrm{gm}) \times$. 


\section{5- Ova diameters:}

Ova diameters were measured to the nearest micron by using an eye piece micrometer. Ova were separated from ovarian tissues, as it immersed in saline solution $(0.99 \% \mathrm{NaCl})$ for 24 hours and measured under the microscope at a magnification power of $40 \times$. The averages of the largest 10 Ova were calculated.

\section{6- Fecundity:}

Fecundity was estimated by counting all mature yolky eggs found in the female ovary just prior to spawning season. A small piece of fish ovary was taken and put in small divided Petri - dish, ova were separated from other tissues with the aid of dissecting needle and the yolky ova were counted under binocular microscope.

\section{RESULTS}

\section{1-Sex ratio}

Generally there is a tendency for more male (58 fish $=14.9 \%)$ than female (19 fish $=4.9 \%$ ) for the whole population, overall sex ratio was males to females (Table1). The sex ratio was not constant throughout the different months.

The maximum percentage of females was recorded in the period from October to December $2010(17.4 \%)$, while the maximum percentage of males was recorded in November $(72 \%)$.

Table 1: Monthly variations in sex ratio of $S$. salpa.

\begin{tabular}{|c|c|c|c|c|}
\hline Monthly & No. of fish & Male No. & Female No. & Sex ratio \\
\hline May 2010 & 26 & 4 & 1 & $1: 0.25$ \\
Jun. & 25 & 1 & - & - \\
Jul. & 25 & 1 & 2 & $1: 1.2$ \\
Aug. & 25 & 11 & 1 & $1: 0.1$ \\
Sep. & 21 & 3 & - & - \\
Oct. & 23 & 10 & 4 & $1: 0.4$ \\
Nov. & 25 & 18 & 7 & $1: 0.4$ \\
Dec. & 23 & 2 & 4 & $1: 1.2$ \\
Jan 2011 & 25 & 1 & - & - \\
Feb. & 21 & 5 & - & - \\
Mar. & 25 & 1 & - & - \\
Apr. & 25 & - & - & - \\
May. & 25 & - & - & - \\
Jun. & 25 & 1 & - & - \\
Jul. & 23 & - & - & - \\
Aug. & 25 & - & - & - \\
\hline Total & $\mathbf{3 8 7}$ & $\mathbf{5 8}$ & $\mathbf{1 9}$ & $\mathbf{1 : 0 . 3 2}$ \\
\hline
\end{tabular}

\section{2-First sexual maturity}

The first appearance of mature males was recorded at length group (18.1$21 \mathrm{~cm})($ Table 2) and the smallest mature male of $S$. salpa attained at length group (21$24 \mathrm{~cm}$ ) (Fig. 1). The first sexual maturity was reported at $22.5 \mathrm{~cm}$. The first mature female was recorded at length group $(24.1-27 \mathrm{~cm})$ and the size at which $50 \%$ of females were mature was $28.5 \mathrm{~cm}$. 
Table 2: Percentage frequency distribution of mature and immature

fishes per length groups of $S$. salpa.

\begin{tabular}{|c|c|c|c|c|c|c|c|c|}
\hline \multirow{2}{*}{$\begin{array}{c}\text { Sex } \\
\text { Length }\end{array}$} & \multicolumn{4}{|c|}{ Males } & \multicolumn{4}{c|}{ Females } \\
\cline { 2 - 8 } & \multicolumn{2}{|c|}{ Immature } & \multicolumn{2}{|c|}{ Mature } & \multicolumn{2}{c|}{ Immature } & \multicolumn{2}{c|}{ Mature } \\
\cline { 2 - 8 } & No. & \% & No. & \% & No. & \% & No. & $\%$ \\
\hline $15.1-18$ & - & - & - & - & - & - & - & - \\
$18.1-21$ & - & - & - & - & - & - & - & - \\
$21.1-24$ & 1 & 33.3 & 2 & 66.6 & - & - & - & - \\
$24.1-27$ & 2 & 13.3 & 13 & 86.6 & - & - & - & - \\
$27.1-30$ & 6 & 42.8 & 8 & 57.1 & 1 & 33.3 & 2 & 66.6 \\
$30.1-33$ & 3 & 16.6 & 15 & 83.8 & - & - & 7 & 100 \\
$33.1-36$ & 2 & 28.5 & 5 & 71.4 & - & - & 4 & 100 \\
$36.1-39$ & - & - & 1 & 100 & - & - & 5 & 100 \\
\end{tabular}
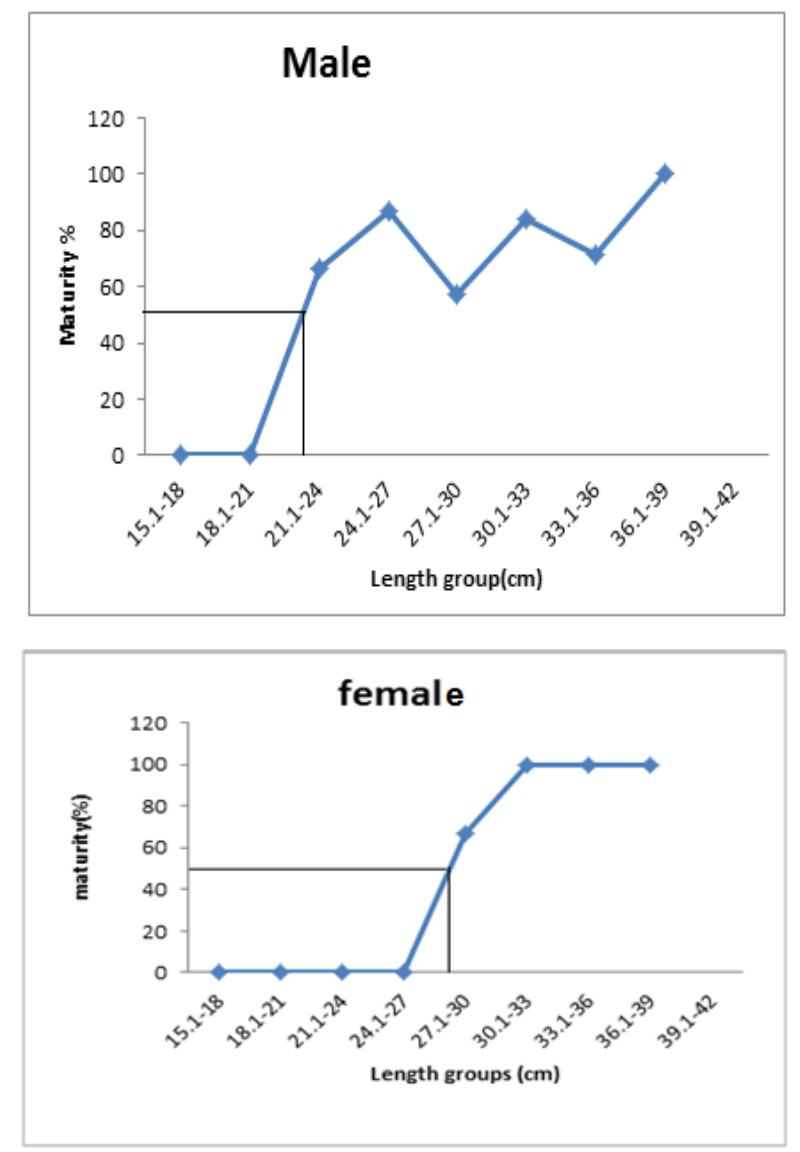

Fig. 1: Length at first sexual maturity for both sexes of S. salpa.

\section{3-Maturity stages:}

Data of monthly changes in maturity stages are illustrated in Table (3) and represented graphically in Fig.2. In males, the testes were immature in May, June and July 2010 (100\%): this immaturity continued to be $36.3 \%$ in August 2010 and reached $66.6 \%$ in September then decreased in the following months. The maturing stage in males was first recorded in August (45.4\%) and increased gradually to the maximum percentage in December (2010) 100\%. The first sign of ripe testes was recorded in August (18.1\%). The highest value recorded in October (90\%).

The ovaries were following the males trend; they were immature in May, June and July 2010 (100\%); immaturity decreased gradually from August and reached the lowest value in January (20\%). In the female, the maturing stage was first recorded 
in December $25 \%$. The first sign of ripe ovaries were recorded in October $(75 \%)$, increased in November (50\%) and increased in December $(75 \%)$.

Table 3: Monthly variations in maturity stages, for both sexes of $S$. salpa.

\begin{tabular}{|c|c|c|c|c|c|c|c|c|}
\hline \multirow{2}{*}{ Monthly } & \multicolumn{9}{|c|}{ Male \% } & \multicolumn{3}{c|}{ Female \% } \\
\cline { 2 - 8 } & $\begin{array}{c}\text { No. of } \\
\text { fish }\end{array}$ & Immature & Mature & Spawning & $\begin{array}{c}\text { No. of } \\
\text { fish }\end{array}$ & Immature & Mature & Spawning \\
\hline May 2010 & 4 & 100 & - & - & 1 & 100 & - & - \\
Jun. & 1 & 100 & - & - & - & 100 & - & - \\
Jul. & 1 & 100 & - & - & 2 & 100 & - & - \\
Aug. & 11 & 36.3 & 45.4 & 18.1 & 1 & 100 & - & - \\
Sep. & 3 & 66.6 & 33.3 & - & - & - & - & - \\
Oct. & 10 & - & 10 & 90 & 4 & 25 & - & 75 \\
Nov. & 18 & 50 & 50 & - & 7 & 50 & - & 50 \\
Dec. & 2 & - & 100 & - & 4 & 25 & 25 & 75 \\
Jan 2011 & 1 & 20 & 60 & 20 & - & - & - & - \\
Feb. & 5 & 100 & - & - & - & - & - & - \\
Mar. & 1 & 100 & - & - & - & - & - & - \\
Apr. & - & - & - & - & - & - & - & - \\
May. & - & - & - & - & - & - & - & - \\
Jun. & 1 & 100 & - & - & - & - & - & - \\
Jul. & - & - & - & - & - & - & - & - \\
Aug. & - & - & - & - & - & - & - & - \\
\hline
\end{tabular}

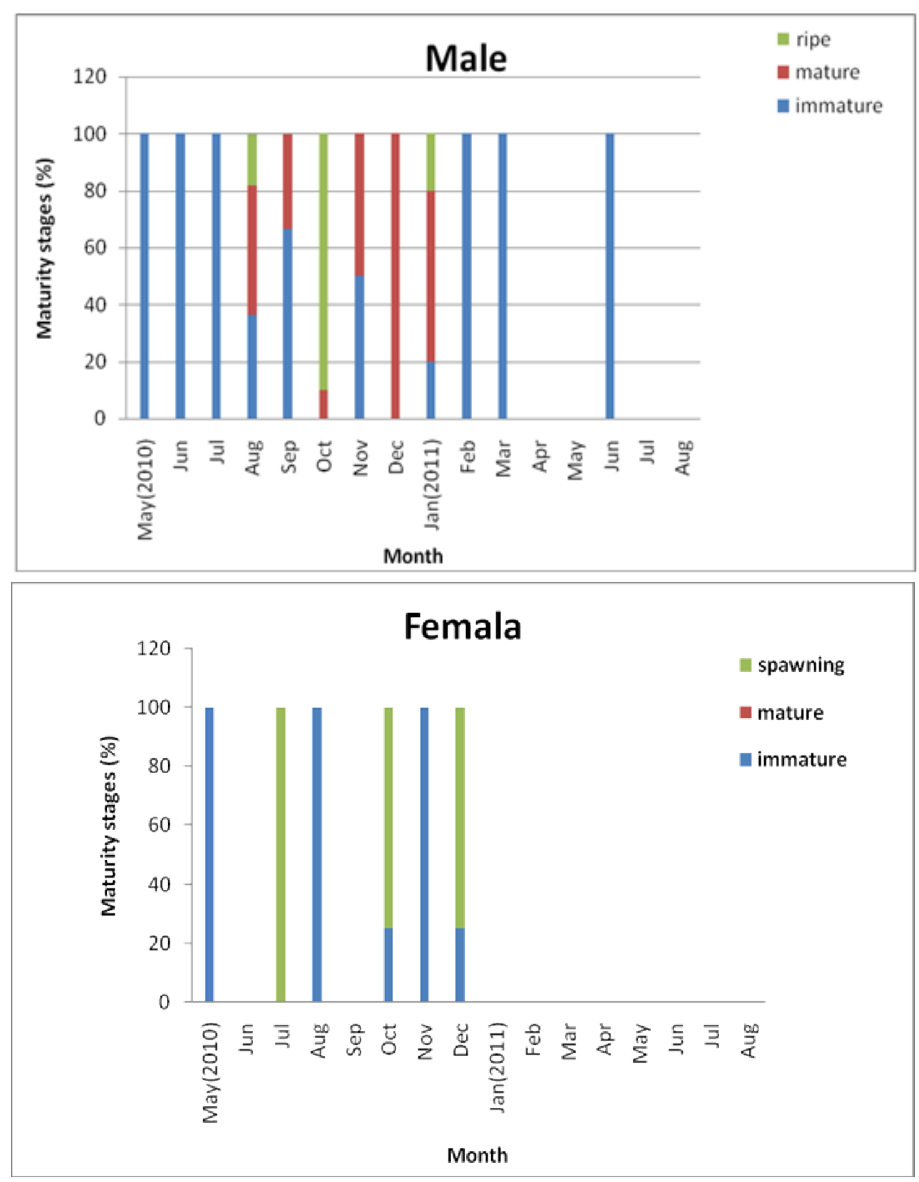

Fig. 2: Monthly variations of the maturity stages in $S$. salpa in both sexes.

\section{4-Gonado-Sometic Index (G.S.I)}

The monthly changes in G.S.I. are represented in Table (4) and Fig. (3). S. salpa has a definite breeding season which extends from October to December. The average 
G.S.I. for males increased gradually from May (0.3) to reach (3.5) in November the maximum values in October (2.5) and November (3.5).

In females the minimum G.S.I. (0.5) was recorded in May 2010, while the highest values were recorded in October (3.1) and November (8.1).

Table 4: Monthly variations of Ganado - Somatic - Index for males and female of S. salpa.

\begin{tabular}{|c|c|c|c|c|c|c|c|c|}
\hline \multirow{2}{*}{ Monthly } & \multirow{2}{*}{$\begin{array}{c}\text { No. } \\
\text { of } \\
\text { fish }\end{array}$} & \multicolumn{3}{|c|}{ male } & \multirow{2}{*}{$\begin{array}{r}\text { No. } \\
\text { of } \\
\text { fish }\end{array}$} & \multicolumn{3}{|c|}{ Female } \\
\hline & & Minimum & Maximum & Aver & & Minimum & Maximum & Aver. \\
\hline May 2010 & 4 & 0.2 & 0.3 & 0.3 & 1 & - & - & 0.5 \\
\hline June & 1 & - & - & 0.3 & - & - & - & - \\
\hline July & 1 & - & - & 0.4 & 2 & 0.1 & 4.1 & 2.1 \\
\hline Aug. & 11 & 0.2 & 2.6 & 0.6 & 1 & - & - & 0.5 \\
\hline Sept. & 3 & 0.2 & 0.5 & 0.4 & - & - & - & - \\
\hline Oct. & 10 & 0.6 & 4.2 & 2.5 & 4 & 1.5 & 5.6 & 3.1 \\
\hline Nov. & 18 & 1.9 & 6.3 & 3.5 & 7 & 5.3 & 10.4 & 8.1 \\
\hline Dec. & 2 & 0.3 & 0.6 & 0.5 & 4 & 0.8 & 2.9 & 1.6 \\
\hline Jan 2011 & 1 & - & - & 0.7 & - & - & - & - \\
\hline Feb. & 5 & 0.5 & 2 & 1.2 & - & - & - & - \\
\hline Mar. & 1 & - & - & 0.7 & - & - & - & - \\
\hline Apr. & - & - & - & - & - & - & - & - \\
\hline May. & - & - & - & - & - & - & - & - \\
\hline June. & 1 & - & - & 0.3 & - & - & - & - \\
\hline July. & - & - & - & - & - & - & - & - \\
\hline Aug. & - & - & - & - & - & - & - & - \\
\hline
\end{tabular}
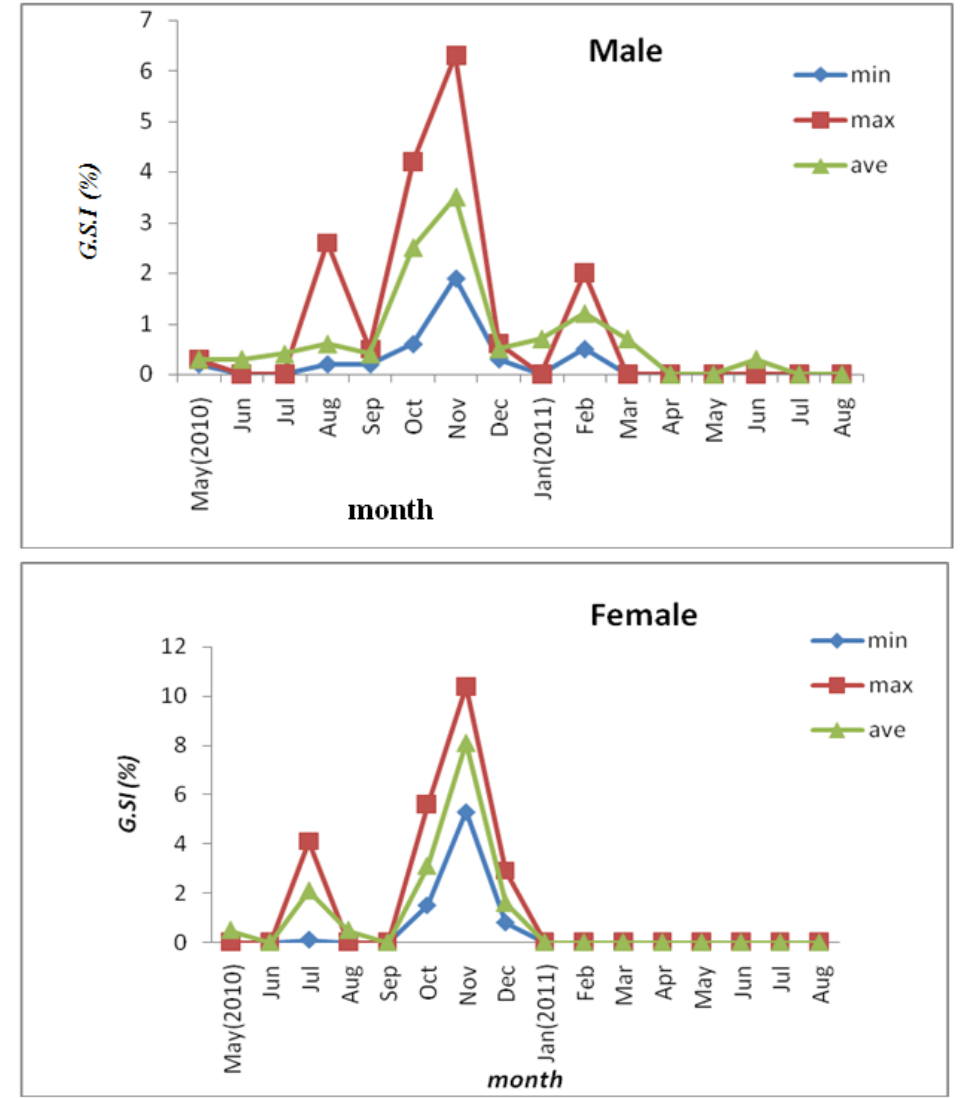

Fig.3: Monthly variations in the average gonado -somatic index for both sexes of $S$. salpa. 


\section{5- Ova diameters:}

The recorded average ova diameters of $S$. salpa during the whole period of study are represented in Table (5) and Fig. (4). Egg diameters were very minute and difficult to measure in the period, April, May 2011 and October, December 2011. The lowest value of the egg diameters was recorded in July and August $2010(0.2 \mu)$, while the highest one was recorded in November $2010(2.7 \mu)$. The maximum average oocytes diameter was recorded from October to December.

Table 5: Monthly variations of ova diameters of $S$. salpa.

\begin{tabular}{|l|c|c|c|c|}
\hline \multirow{2}{*}{ Monthly } & \multirow{2}{*}{ No. of fish } & \multicolumn{3}{|c|}{ Ova -diameter $(\mu)$} \\
\cline { 2 - 5 } & & Minimum & Maximum & Aver. \\
\hline May 2010 & 1 & 0.2 & 0.4 & 0.3 \\
June. & - & - & - & - \\
July. & 2 & 0.1 & 0.3 & 0.2 \\
Aug. & 1 & 0.3 & - & 0.2 \\
Sept. & - & - & - & - \\
Oct. & 4 & 0.4 & 2.5 & 1.6 \\
Nov. & 7 & 2.1 & 3.4 & 2.7 \\
Dec. & 4 & 1.8 & 3.3 & 2.5 \\
Jan 2011 & - & - & - & - \\
Feb. & - & - & - & - \\
Mar. & - & - & - & - \\
Apr. & - & - & - & - \\
May. & - & - & - & - \\
June. & - & - & - & - \\
July. & - & - & - & - \\
Aug. & - & - & - & - \\
\hline
\end{tabular}

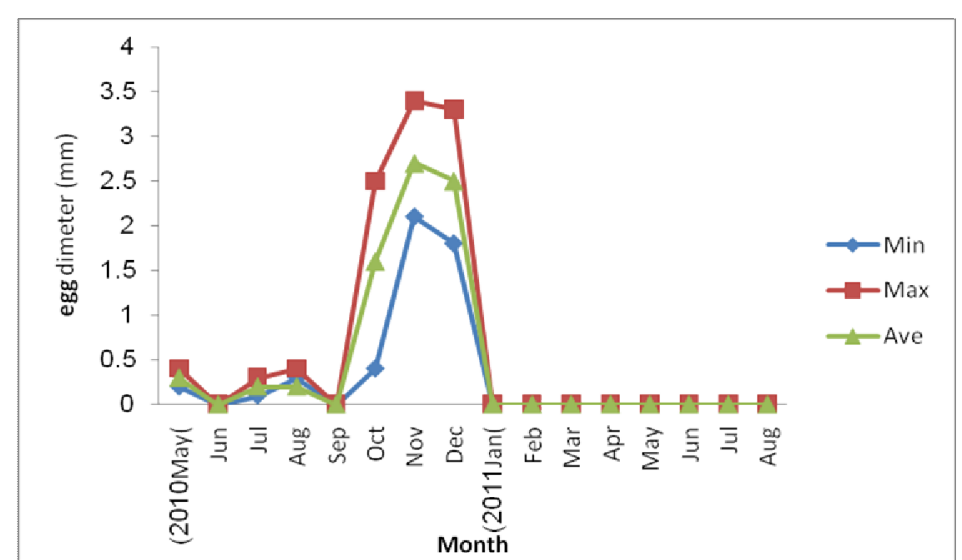

Fig. 4: Monthly variations of ova diameters of females of $S$. salpa.

\section{6- Fecundity}

Two terms are applied in fish fecundity work; the absolute fecundity which is the total number of mature eggs in the ovary and the relative fecundity which is the number of eggs per unit length or weight of the fish (Nikolsky, 1963).

The relationship between the length and absolute fecundity of $S$. salpa is given in Table (6) and Fig. (5).

The absolute fecundity ranged from 22952 to $15,123,096 \mathrm{eggs} /$ fish. (Fig. 5). It is clear that absolute fecundity and relative fecundity increased with the increase of the total length (TL). 
Table (6): The relationship between fecundity and total length (cm) of $S$. salpa.

\begin{tabular}{|c|c|c|c|c|c|c|}
\hline \multirow{2}{*}{$\begin{array}{c}\text { Total } \\
\text { Length } \\
\text { (cm) }\end{array}$} & \multirow{2}{*}{$\begin{array}{c}\text { No. } \\
\text { of } \\
\text { fish }\end{array}$} & \multirow{2}{*}{$\begin{array}{c}\text { Aver. } \\
\text { TL } \\
\text { (cm) }\end{array}$} & \multicolumn{3}{|c|}{ Absolute fecundity } & \multirow{2}{*}{$\begin{array}{c}\text { Relative fecundity } \\
\mathbf{f} / \mathbf{l}\end{array}$} \\
\hline & & & Min. & Max. & average & \\
\hline $27.1-30$ & 3 & 29.5 & 166,750 & $2,978,440$ & $1,283,204$ & 43,498 \\
\hline $30.1-33$ & 7 & 31.7 & 22,952 & $9,602,072$ & $3,344,140$ & 105,493 \\
\hline $33.1-36$ & 4 & 34.5 & 38,658 & $15,123,096$ & $4,782,124$ & 138,612 \\
\hline $36.1-39$ & 5 & 38.4 & 283610 & $2,791,404$ & $1,136,999$ & 29,609 \\
\hline
\end{tabular}

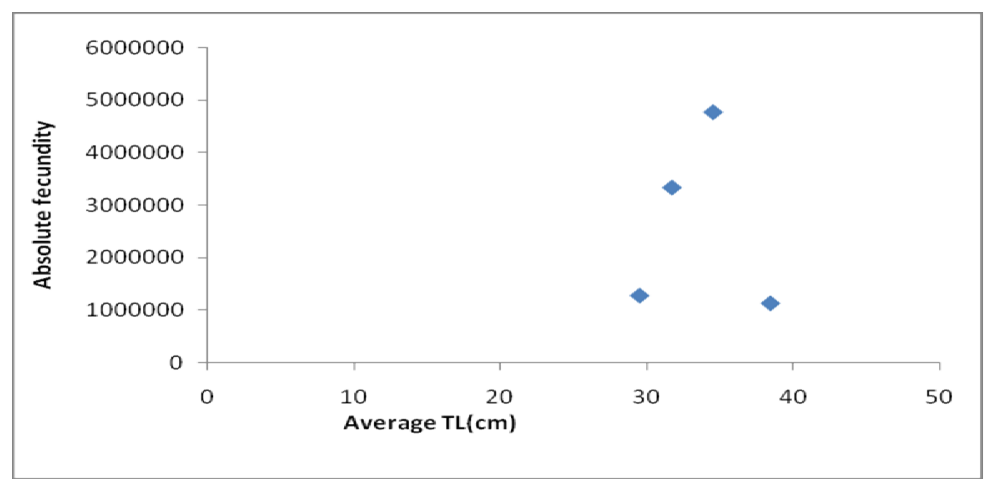

Fig. 5: Relationship between total length $(\mathrm{cm})$ and average absolute fecundity of $S$. salpa.

The results of the relationship between the absolute fecundity and body weight are given in Table (7) and Fig. (6). Absolute fecundity ranged from 22, 952 to15, 123, 096.

It is clear that the absolute fecundity increased with increasing of body weight to 400 gm.; then decreased after that to reach its minimum value at 1000 gm, body weight (WT).

Table 7: Relationship between fecundity and total weight (gm) of S. salpa.

\begin{tabular}{|c|c|c|c|c|c|c|}
\hline \multirow{2}{*}{$\begin{array}{c}\text { Total } \\
\text { weight } \\
\text { (gm.) }\end{array}$} & \multirow{2}{*}{$\begin{array}{l}\text { No. } \\
\text { of } \\
\text { fish }\end{array}$} & \multirow{2}{*}{$\begin{array}{c}\text { Aver. } \\
\text { wt. (gm.) }\end{array}$} & \multicolumn{3}{|c|}{ Absolute fecundity } & \multirow{2}{*}{$\begin{array}{l}\text { Relative } \\
\text { fecundity } \\
\text { f/w }\end{array}$} \\
\hline & & & Min. & Max. & Average & \\
\hline $300.1-400$ & 3 & 386.1 & 704,424 & $2,978,440$ & $2,158,089$ & 5,589 \\
\hline $400.1-500$ & 3 & 449.9 & 166,750 & $15,123,096$ & $5,528,183$ & 12,287 \\
\hline $500.1-600$ & 3 & 553.1 & $2,208,440$ & $9,602,072$ & $6,205,509$ & 11,219 \\
\hline $600.1-700$ & 3 & 617.2 & 22,952 & $2,841,868$ & $1,477,886$ & 2,394 \\
\hline $700.1-800$ & 1 & 761.6 & - & - & $1,124,875$ & 1,476 \\
\hline $800.1-900$ & 4 & 849.0 & 38,658 & $2,791,404$ & 866,540 & 1020 \\
\hline $900.1-1000$ & 1 & 918.8 & - & - & $1,685,729$ & 1,834 \\
\hline $1000.1-1100$ & 1 & 1006 & - & - & 571.764 & 568 \\
\hline
\end{tabular}

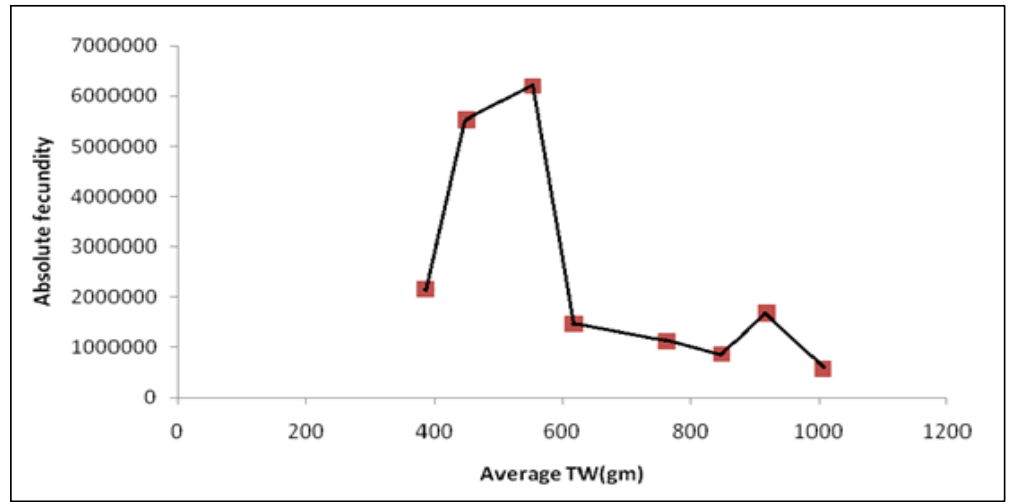

Fig. 6: Relationship between total weight (gm) and average absolute fecundity of $S$. salpa (hand made curve). 


\section{DISCUSSION}

Salema's trophic role in coastal ecosystems was quite well understood, but few studies in the past have researched into the biological parameters of this species, especially in the Mediterranean. Therefore, in this study we tried to furnish new data on its life cycle. Analysis of gonads confirmed that $S$. salpais a protandrous hermaphrodite species; therefore, it changes sex from male to female during its life. Proterandric hermaphroditism in salema has already been observed in the Mediterranean sea (Lissia-Frau, 1966; Lissia-Frau and Casu, 1968), in the eastern Atlantic Ocean (Mendez-Villamil et al., 2002), and in the western Indian Ocean (Van der Walt and Mann, 1998). The overall ratio between males and females of S.salpa was 1:0.32 such differences could be due to migration and or behavioural differences between sexes (Polonsky and Tormosova, 1969). Ahmed, (1999) found that in south Sinai coasts, females outnumber the males in $S$. salpa. In these species sex change in an alternative reproductive style that enables individuals to maximize their life time reproductive success by functioning as one sex when small and the other sex when large (Buxton and Garratt, 1990).

Ahmed (2012) studied the reproductive biology of crenidens (family sparidae), alessepsian migrant species inhabiting Libyan eastern coast and he found that the overall sex ratio was 1:1.03 for male to female.

In the present study the fish $S$. salpa show that the breeding season runs from August to November (Both \& Buxton, 1997; FAO, 2000; Hood \& Johnson, 2000; Ahmed, 1999). The eastern coast of Libya, salema spawn during two period of the year autumn (September-November).

A similar reproductive cycle has been observed in along the Tunisian waters (Sellami and Bruslè, 1975; Anato and Ktari, 1983), and in the Canary Islands (Mendez-Villamil et al., 2001), salema spawn during a single period that extends throughout the autumn and winter months. The size-at-maturity of males $(21.1 \mathrm{~cm})$ didn't differ significantly from the value observed in the Canary Islands $22.6 \mathrm{~cm}$ (Mendez-Villamil et al., 2002).

Fecundity is an important item in studying the fish reproduction (Nikolosky, 1965). It shows a wide variation among different species, and also with the same length and age. It also fluctuated according to different environmental conditions (Amein, 1996). Even within a stock, fecundity is known to vary annually, undergo long term changes (Horwood et al., 1986) and has been shown to be proportional with fish size and environmental condition. Larger fish produce more eggs, both in relative and absolute terms to body mass. For a given size female in better conditions exhibit higher fecundity (Kjesbu et al., 1991). Moyle and Cech (1982) mentioned that fecundity is related to food supply. As results, well fed fish can produce more and larger eggs. On the other hand, parasitic infection densities, with corresponding increase in behavioral interactions, may cause a reduction in fecundity (Kipling and Frost, 1969; Bangenal, 1971 and Hanaffy and Gaballa, 1998).

Absolute fecundity ranged from 1,136,999 to 4,782,124 in the total length ranged 27.1-39 cm as well as from 571,764 to 6,205,509 in total weight range 300.1$1100 \mathrm{~g}$.

These values agree or disagree with the results of others depending on the different methods of counting and geographical and environmental conditions surrounding fishing grounds. The data obtained represents only a first step in the study of $S$. salpa as it is important to analyses the influence that salema, one of the most abundant species in areas characterized by rocky bottoms and seagrass meadows 
(Verlaque, 1990 and Dulcic et al., 1997 \& Francour, 1997), exerts on the coastal fish assemblages.

\section{REFERENCES}

Ahmed, A.I. (1999). Biological and ecological studies on some sparidae fishes from southern Sinai coasts (Red sea). ph. D. Thesis Fac. Sci, Suez Canal Univ. 261pp.

Ahmed, A.I. (2012). Reproductive Biology of the Egyptian Sabaraus Crenidens (Forsskal, 1775), in the Libyan Eastern Coast, Libya. Journal of Life Sciences; Apr 2012, Vol. 6 Issue 4, p.421.

Alessandro, C.C; Fransco, C. Paolo, B; Andrea and Giandomenico, A. (2006). Observations on the reproductive cycle, age and growth of the salema, $S$. salpa (Osteichtyes: Sparidae) along the Western Central Coast Italy. Sci Mar, 70: 1 .

Amin, A.M.M. (1996). A study of the biology and population dynamics of Litherinus bungus (Forsskal, 1775) in the Gulf of Suez, Egypt. M.Sc. Thesis, Marine Science Department, Faculty of Science, Suez Canal University Egypt.

Anato, C. B and M.H. Ktari. (1983). Reproduction de Boops boops (Linné, 1758) et de Sarpa salpa (Linnè, 1758), Poissons Téléostéens, Sparidés du Golfe de Tunis. Bull. Inst. Nat. Scient. Tech. Océanogr. Pèche, Salammbo, 10: 49-53.

Bangenal, T. (1971). Egg and early life history In: Methods of assessments of fish production in fresh waters. I.B.P. Blackwell Sci. Pupl. Oxford, 166-199.

Belgin, H and Raziye, Y (2003). Some biological barometers of round herring. Etrumeusteres (D.C Kay, 1842) in the Gulf of Antalyor (Mediterranean Sea). E.U Journal of Fisheries \& Aquatic Sciences. Volume 20, Sax/Issue (1-2): 1-8.

Billard, R. and Breton, B. (1978). Rhythms of reproduction in teleost fish In; Rhythmic activity of fishes .31-53.Thorpe J.E (ed)London \& New York .Academic press.

Both, A.J. and Buxton, C.D. (1997). The biology of the Pang apeterogymnus iniarius (Teleostei; sparidae) on the Agulhas bank South Africa .Environmental Biology of Fishes 49(2).

Buxton, C.D. and Garratt, P.A. (1990). Alternative reproductive styles in seabreams, Environmental Biology of Fishes, 28 pp. 113 - 124. ISSN 0378-1909 ss.

De Vlamming, V.; Grossman, G. and Champman, F. (1982). On the use of the gonad somatic index. Comp. Biochem. Physiol.81; 117-120.

Dulcic, J., M. Kraljevic, B. Grbec and A. Pallaoro (1997). Composition and temporal fluctuations of inshore juvenile fish populations in the Kornati Arcipelago, eastern middle Adriatic. Mar. Biol., 129(2): 267-277.

FAO. (2000). Fishery country profile. http;//www.fao.org

Fouda, F. (1989). Biological and physiological studies on Goby fishes from Timsah Lake. Ph. D. Thesis, Fac of Girls, Ain Shams Univ., Cairo, Egypt

Francour, P. (1997). Fish assemblages of Posidonia oceanica beds at Port-Cros (France, NW Mediterranean): Assessment of composition and long-term fluctuations by visual census. Mar. Ecol., 18(2): 157-173.

Hanaffy, M. and Gaballa, A. (1998). Effect of Gondal infection by Mematoda parasitic on fecundity of Lithernus nadbulosus in Ras Mohammed, Marine park, Northern Red sea. Egypt. J. Aquat. \& Fish., 2:19-34. 
Hjort, J. (1910). Report on herring investigation until January 1910. publ. Circons, Cons. Perm Explor Mer., 53:1

Hood, P.B. and Johnson, A.K. (2000). Age, growth, mortality, and reproduction of porgy, pagrus pagrus, from the eastern Gulf of Mexico, fish .bull.98:723735.

Horwood, J., Bannister, R. and Howlett, G. (1986). Comparative fecundity of North Sea Place. Proc. R. Soc. Lond. B. 228:401-431.

Kipling, C. and Frost, W. (1969). Variation in fecundity of Pike, Esoz lucius (L.) in windermere. J. Fish. Biol., 1:221-237.

Kjesbu., O., Klungsoyr, J.; Kryvi, H.; WIthames, P. and Green W. (1991). Fecundity, atresia, and egg size of captive Atlantic Cod Gadus morhua in relation to proximate body composition. Can. J. Fish aquat. Sci., 48:2333-2343.

Lissia Frau, A.M. (1966). Ricerche sul differenziamento sessuale di Boops salpa (L.) (Teleostei, Sparidae). Atti Accad. Gioenia Sci. Nat. 6 ser., 18: 165-174.

Lissia Frau, A.M. and S. Casu. (1968). Il processo gonado genetic in alcune specie di Sparidi (Teleostei, Perciformes). Studi Sassaresi, 1:1-23.

Mendez-Villamil, M., J. M. Lorenzo, J. G. Pajuelo, A. Ramos and J. Coca. (2002). Aspects of the history of the salema, S. salpa (Pisces, Sparidae), off the Canarian Arcipelago (centraleast Atlantic). Environ. Biol. Fish., 63: 183-192.

Mendez-Villamil, M., J.G. Pajuelo, J. M. Lorenzo, J. Coca and A. Ramos. (2001). Age and growth of the salema, Sarpa salpa (Osteichthyes, Sparidae) off the Canary Islands (East-central Atlantic). Arch. Fish. Mar. Res., 49(2): 139148.

Moyle,B. and Cech, J. (1982). An introduction to Ichtyology. Rentice hall, Inc. England Cliff, N.J. 7632:110-111.

Nikolosky, G. (1963). The ecology of fishes. Academic Press, London. (Translated from Russian, L. Brikett), 352pp.

Pitt, T. (1970). Distribution, abundance and spawning of yellow tail flounder, Limanda ferruginea, in the New found land area of the north west Atlantic. J. Fish. Res. Bd. Canada, 27 (1):2261-2271.

Polonsky, A. and Tormosova, I. (1969). The spawning of the jack- mackerel of the Northeast Atlantic and the distribution of its eggs and larvae. Trady. Atl Nauchno-Issled. Inst. Rybn. Khoz. Okeanogr. 23:27-48 [In Russian].

Sellami, A. and J. Bruslé. (1975). Contribution a l'étude de la sexualité de la saupe Boops salpa Linnaeus 1758 (téléostéen Sparidae) des cotes de Tunisine. Vie Milieu, 25: 261-275.

Shakman, E. A.(2008). Lessepsian Migrant fish species of the Coastal waters of Libya: status, Biology, Ecology. U7niversitat Rostock, Germany vol,40-41.

Sott, DBC (1979). Environmental timing and control of reproduction in telost fish .sym .Zool. Soc. land. 44:105-132.

Van der Walt, B.A. and B.Q. Mann. (1998). Aspects of the reproductive biology of $S$. salpa (Pisces: Sparidae) off the east coast of South Africa. S. Afr. J. Zool., 33(4): 241-248.

Verlaque, M. (1990). Relationship between S. salpa (L.) (Teleostei, Sparidae), other browser fishes, and the Mediterranean algal phytobenthos. Oceanol. acta, 13(3): 373-388. 


\section{ARABIC SUMMARY}

دراسة بيولوجية لتكاثر سمكة (السربا سلبا) على الساحل الليبي للبحر المتوسط

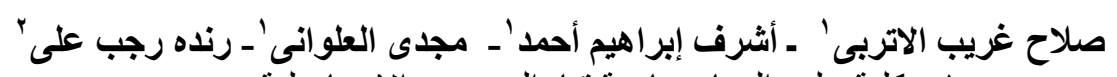

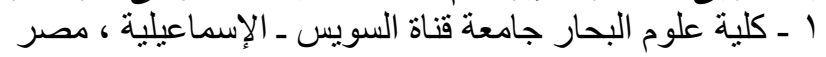

r- جامعة عمر المختار ـ ليبيا

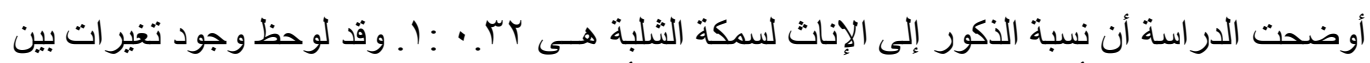

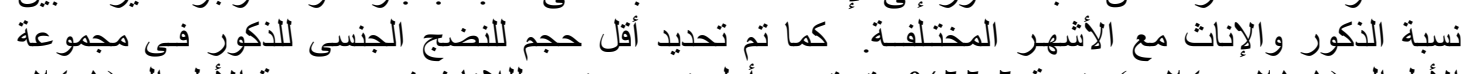

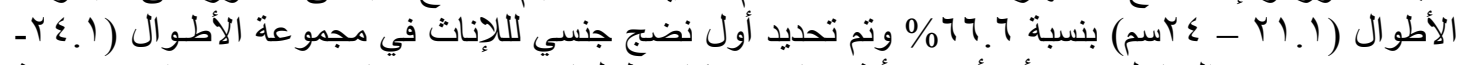

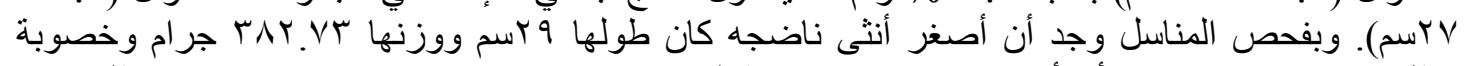

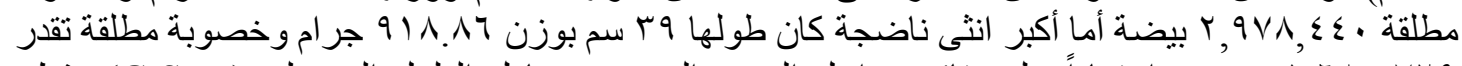

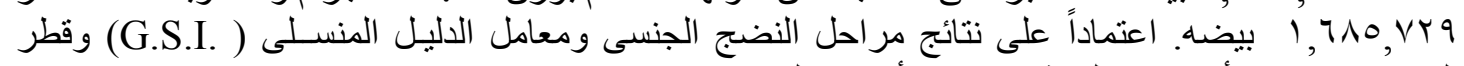
البيويضات، وجد أن موسم التكاثر يمتد من أكتوبر إلى ديسمبر النير. 